\title{
Using distance learning as a strategy for maintaining income of Physical Education professionals during the COVID-19 pandemic
}

\author{
Mayara Torres Ordonhes ${ }^{1}$ (D) Emilia Devantel Hercules $^{1}$ (D) \\ Fernando Renato Cavichiolli ${ }^{1}$ (iD
}

Received: 24 December 2020 / Accepted: 11 April 2021 / Published online: 29 April 2021

(c) The Author(s), under exclusive licence to Springer Science+Business Media, LLC, part of Springer Nature 2021

\begin{abstract}
The period of social distancing caused by the COVID-19 pandemic is characterized as an effective proposal to control the spread of the coronavirus (SARS-CoV-2), however, it changes the social dynamics of individuals in society. Based on this question, the present study aimed to understand how was the performance of Brazilian physical education professionals during this period. The sample consisted of 400 Physical Education professionals from Brazil, 224 women (56.0\%) and 176 men $(44.0 \%)$, selected at random, by filling out a questionnaire. Sports activities were predominant among professionals, followed by bodybuilding activities or functional training. Most professionals performed their activities at home (71\%) and used different digital platforms as work tools, noting that distance learning was a strategy used and well regarded by professionals. However, even with the use of specific intervention strategies, professional income showed fluctuations during the pandemic, with academic degrees being one of the factors responsible for changing the workload.
\end{abstract}

Keywords Physical education and training · Coronavirus · Quarantine · COVID-19 . ELearning

\section{Introduction}

In mid-2019-2020, a particular virus drew worldwide attention: the coronavirus (SARS-CoV-2). The virus causing the disease COVID-19 was detected on December 31, 2019 in Wuhan (China), a time when the World Health Organization (WHO)

Mayara Torres Ordonhes

mayaraordonhes@hotmail.com

1 Department of Physical Education, Federal University of Paraná, Coração de Maria, 92, Jardim Botânico, Curitiba, PR, Brazil 
warns, disclosing its circulation in January 2020 (Lana et al., 2020). Since then, cases have been identified in other countries such as Japan (January 16), United States (January 21), Canada (January 23), Australia (January 25), Italy (January 31), Spain (February 1), Brazil (February 7), among others, characterizing the new virus as a worldwide pandemic (March 11) (Lana et al., 2020; Estadão, 2020; Tass, 2020; Corriere della Sera, 2020; El país, 2020; BBC, 2020; Lewnard \& Lo, 2020; Aquino et al., 2020).

Coronavirus (COVID-19) is an infectious respiratory disease that can manifest itself in a mild, moderate or severe manner, in addition to this, due to rapid contamination (Aquino et al., 2020) and concern about the capacity of health systems, the indication of the responsible bodies consisted of social distancing (World Health Organization, 2020), considering that in the absence of pharmaceutical intervention, reducing contact with people is a positive strategy (Lewnard \& Lo, 2020; Aquino et al., 2020). Social distancing is the measure that seeks to reduce human interactions, through the closing of schools and workplaces, restrictions on trade or even the complete lockdown of a region (Aquino et al., 2020; Bastos \& Cajueiro, 2020; Ganem et al., 2020).

However, although this proposal to control the spread of the virus-when associated with other measures such as cough etiquette, increased testing capacity and case isolation—has scientifically proven benefits (Lewnard \& Lo, 2020; Bastos \& Cajueiro, 2020), it provides changes in the social dynamics of different spheres of society (Aquino et al, 2020). In the case of sport, several national and international competitions were suspended (Nicola et al., 2020), mainly after the position of the entities responsible for the development of sport as favorable for suspension of sporting activities, such as the International Olympic Committee (Olympic, 2020; International Olympic Committee, 2020). Besides that, based on the principles of prevention and flattening the curve of contamination (Bastos \& Cajueiro, 2020; Ganem et al., 2020), specific decrees were published by Brazilian municipalities and states restricting the opening of sports facilities (Aquino et al., 2020) such as sports schools and gyms (Aquino et al., 2020; Gilat \& Cole, 2020; Hammami et al., 2020; Corsini et al., 2020).

From this moment on, physical education professionals began to reinvent themselves. The increase in physical inactivity, sometimes linked to the emotional state of individuals (Wang et al., 2020) during social distancing, contributed to the emergence of new intervention proposals, carried out primarily remotely, through digital platforms. However, it is not known how this process of readaptation of professionals was, considering that before the pandemic of COVID-19 the use of remote education was observed-sometimes-as a distant reality from physical education (Mello et al., 2021; Cruvinel et al., 2015).

Although several studies have been conducted on the importance of social distancing (Aquino et al., 2020; Bastos \& Cajueiro, 2020; Ganem et al., 2020) and psychological (Pappa et al., 2020) or economic (Nicola et al., 2020) impacts, it was not possible to verify studies related to the reorganization of the work of these professionals whose primary function is to guide the human movement through individual or group activities. Therefore, in order to understand how this process took place, the present study aimed to analyze the performance of Physical Education 
professionals during the COVID-19 pandemic, and is justified considering that this demand arose relatively quickly, induced by the emerging need during the COVID19 pandemic in the country.

\section{Method}

\subsection{Sample and study design}

Participants were 400 Physical Education professionals from Brazil (Ethics Committee of the Federal University of Paraná, CAAE 88,770,618.4.0000.0102, opinion 2.748.001), selected at random, by filling out a questionnaire.

\subsection{Procedures and data analysis}

In order to apply the questionnaire, it was decided to use the Google Forms tool. The questionnaire had 25 questions (open and closed) and was made available for completion between May 13, 2020 to June 1, 2020, a period established based on the closing and opening of the facilities for sports practice, which started the resumption of activities on the first day of the month of June. The questionnaire was filled out anonymously, thus, all information obtained was translated in coded form, maintaining the confidentiality of the participants.

After the end of the data collection, responses were exported and inserted into the SPSS software (IBM Corp, Armonk, NY, USA) version 25, in order to run the statistical analysis. In addition to the analysis of descriptive statistics (frequencies), the Kolmogorov-Smirnov test $(n>50)$ was applied with Lilliefors correction, to check data normality. Through the test, a significant value was obtained $(p<0.05)$, thus, it can be said that the distribution of data in question was not normal (Agresti \& Finlay, 2012; Field, 2009).

Subsequently, the following tests were performed: $\mathrm{H}$ of Kruskal-Wallis, U of Mann-Whitney (with Bonferroni correction), Pearson's chi-square. The size of the effect will be calculated by Cohen's d (0.20, small; 0.50, medium; and 0.80, large). Finally, the Multinomial Logistic Regression test was performed, respecting the necessary prerequisites, such as the absence of multicollinearity between the variables analyzed, the absence of outliers and a significant sample.

\section{Results}

The sample consisted of 400 Physical Education professionals, 224 women (56.0\%) and 176 men (44.0\%), thus, no subject was excluded from the analysis. Of the total number of participants, 296 individuals are from the south of the country $(74.0 \%)$, 86 are from the southeast $(21.5 \%), 11$ are from the center-west $(2.8 \%)$, six from the 


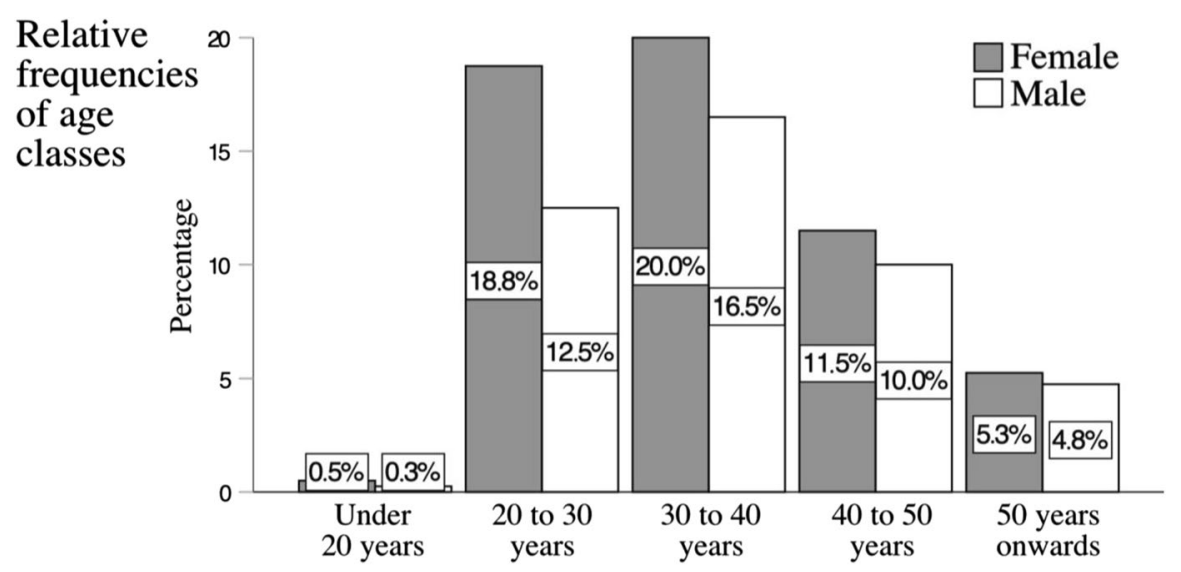

Fig. 1 Distribution of the relative frequencies of age classes according to sex

northeast $(1.5 \%)$ and only one from the north $(0.3 \%)$. The frequencies and percentages of the age classes are illustrated in Fig. 1.

Most of the participants (36.5\%) were between 30 and 40 years old and the sample was composed predominantly of women. The frequencies and percentages of academic degrees of these participants are shown in Fig. 2.

To identify the characterization of pedagogical practices, activities developed by the professionals was surveyed, as shown in Fig. 3.

Sports activities were predominant among professionals, followed by bodybuilding activities or functional training. To check the place where these activities were carried out, participants were asked about the environment used and it was found

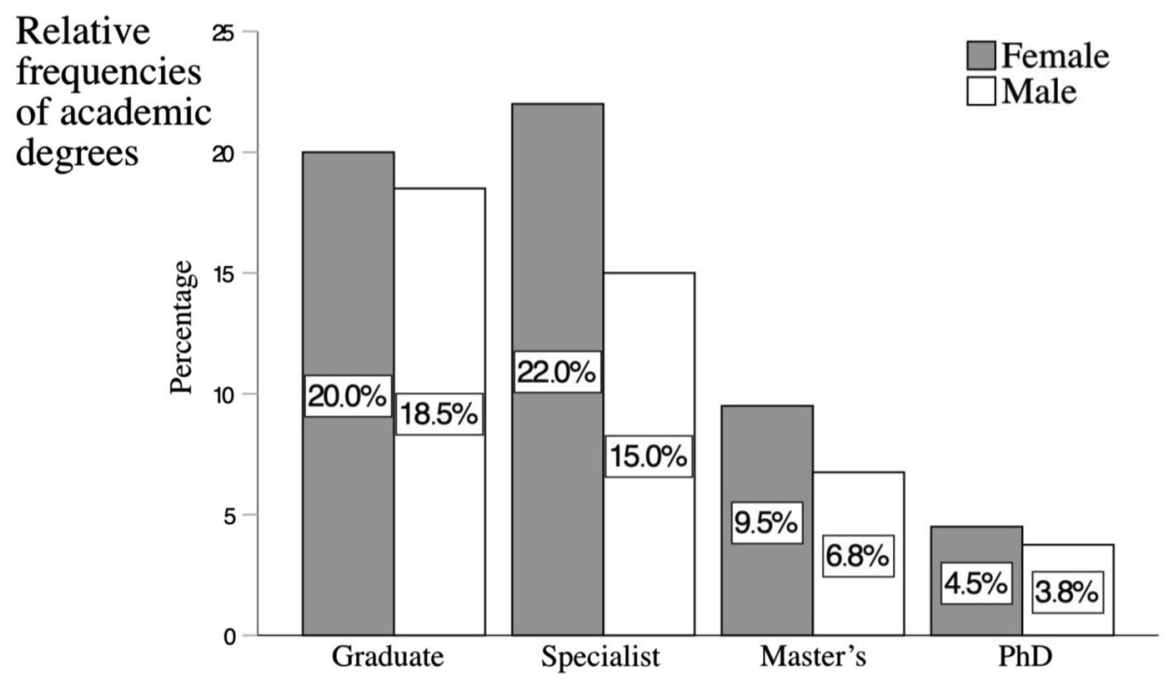

Fig. 2 Distribution of the relative frequencies of academic degrees according to sex 


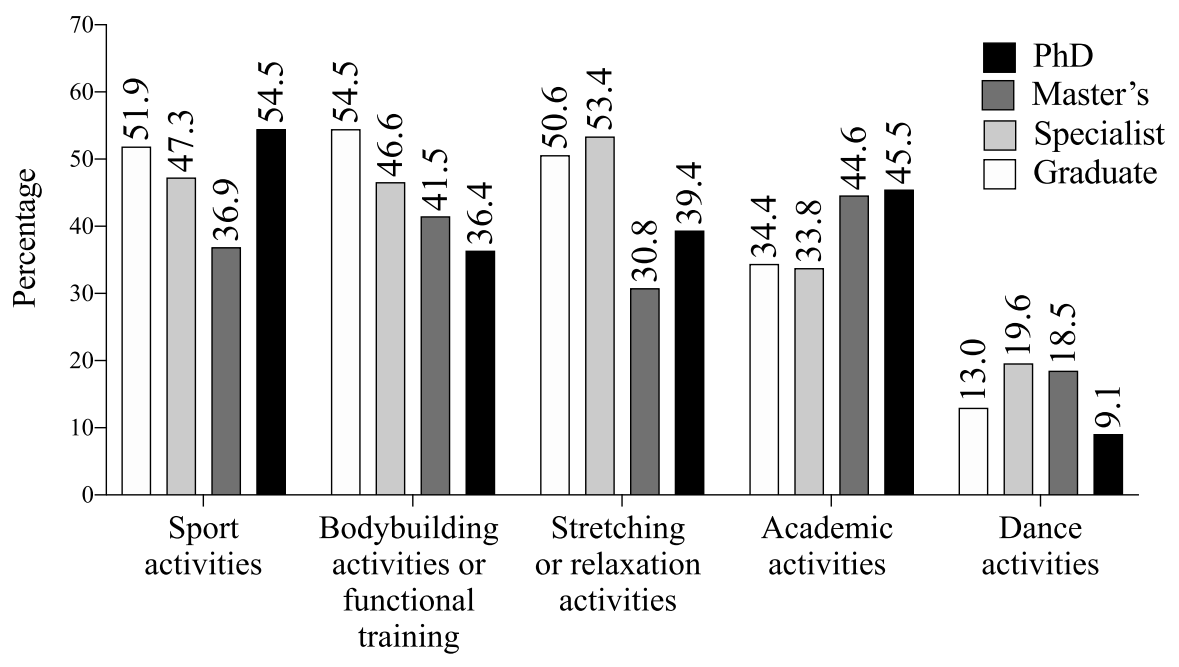

Fig. 3 Distribution of the relative frequencies of proposals according to the academic degree

that $71 \%$ professionals performed their activities at home. Of these, $47.8 \%$ used the room in their homes as a working environment.

Activities were carried out predominantly through the prior elaboration of the contents (45.5\%), made available through digital platforms such as Instagram, Facebook, Whatsapp, Youtube, Google classroom, Microsoft Teams, among others.

To check for differences between the amount of work (daily, weekly and total workload) during the COVID-19 period in the respective academic degrees, the Kruskal-Wallis test for independent samples was applied.

The test evidenced the effect of the gAroups (academic degree) on the daily workload $\left[\mathrm{X}^{2}(3)=37.774 ; p<0.001\right]$ and week workload $\left[\mathrm{X}^{2}(3)=17.769 ; p<0.001\right]$. Subsequently, to identify between which groups there were differences, post hoc tests with pairwise comparisons were performed using the Mann-Whitney U test (with Bonferroni correction), followed by the calculation of the magnitude of the effect (Cohen's $d$ ) (Table 1).

The strongest effect occurred between graduates and $\mathrm{PhDs}$, both on the daily hours worked $(d=0.43)$ and on the days per week worked $(d=0.30)$. However, it is also possible to identify moderate effects between specialists and $\mathrm{PhDs}(d=0.33$ for daily hours and $d=0.27$ for days per week), in addition to master's and PhDs ( $d=0.34$ for daily hours and $d=0.27$ for days a week).

Of the total number of participants, about $49 \%$ professionals said they were working less than before the social distancing caused by COVID-19, however, $40.5 \%$ said they were working more than before and only $10.5 \%$ did not report changes in workload. To check for financial impacts of the proposed social distancing during the COVID-19 pandemic period, we questioned the professional financial income during this period (Table 2).

The majority of individuals showed a reduction in income during the period of social distancing $(n=211,52.8 \%)$. On the other hand, about $44.3 \%(n=177)$ 
maintained their income, and only 3.0\% $(n=12)$ showed an increase. To check for influences from the prior experience on the use of technological resources and the receipt of training by educational institutions on the maintenance of individuals' income, the Multinomial Logistic Regression test was carried out (Table 3).

The test indicated no statistically significant values $(p>0.05)$, thus, it can be verified that the a priori experience on the use of technological resources and the receipt of training by educational institutions did not influence income maintenance during the COVID-19 pandemic period.

When questioning the participants about considering Distance Learning as a possibility of work in this moment of social distancing, about 369 individuals said yes $(92.3 \%)$. In addition, 261 professionals $(65.3 \%)$ stated that carrying out activities proposals remotely can be used in the area of Physical Education even after the period of social isolation during the COVID-19 pandemic.

\section{Discussion}

Regarding the universe of physical education professionals, there can be a change in working time of these professionals during the period of social distancing caused by the COVID-19 pandemic (Bezerra et al., 2020). Most professionals showed changes in working time, more or less, with only a minority of professionals who did not show significant changes in the number of hours and days worked. The reason for this contrast may have been the consequences of the implemented social distancing measures (World Health Organization, 2020; Aquino et al., 2020; Bastos \& Cajueiro, 2020; Ganem et al., 2020), considering that these had a significant and direct impact on the field of action of the physical education professional, through the closure of educational establishments and gyms, in addition to the limitation of permanence in parks and sports institutions (Aquino et al., 2020; Gilat \& Cole, 2020; Hammami et al., 2020; Corsini et al., 2020). Another factor that may have contributed to this scenario refers to the modification of the individuals' daily activities, due to the social and economic difficulties encountered, mainly those related to physical activities and sport.

Another aspect highlighted is the difference between working time as a function of academic degree. In relation to this, it is assumed that the $\mathrm{PhDs}$ presented differences in the hours and days worked from all other degrees, considering that these continued the work in the scope of undergraduate and graduate programs. At times when practical activities were suspended, the continuation of academic work remotely was intensified (Farias \& Giordano, 2020).

The analyses carried out in this study revealed that the factors influencing the income of physical education professionals go beyond aspects such as the experience with the use of technological resources and the receipt of training by educational institutions, that is, the fact that Physical education professionals know-or not-how to use different technological resources did not cause significant interference. This was probably because professionals sought to update themselves in relation to specific applications related to practical intervention in order to be 
Table 1 Post hoc analyses with pairwise comparisons between different categories

\begin{tabular}{|c|c|c|c|c|c|c|c|c|}
\hline \multicolumn{5}{|l|}{ Daily hours worked } & \multicolumn{4}{|c|}{ Days per week worked } \\
\hline Category 1 - Category 2 & $U$ & $z$ & $p^{*}$ & $d$ & $U$ & $z$ & $p^{*}$ & $d$ \\
\hline Graduate-Specialist & -35.193 & 12.535 & $0.030 * *$ & 0.17 & -18.249 & 12.458 & 0.858 & 0.09 \\
\hline Graduate-Master's & -41.575 & 16.108 & 0.059 & 0.17 & -20.555 & 16.008 & 1.000 & 0.08 \\
\hline Graduate-Master's & -124.817 & 20.890 & $0.000 * *$ & 0.43 & -87.195 & 20.761 & $0.000 * *$ & 0.30 \\
\hline Specialist_Mestre & -6.382 & 16.204 & 1.000 & 0.03 & -2.306 & 16.104 & 1.000 & 0.01 \\
\hline Specialist-PhD & -89.624 & 20.964 & $0.000 * *$ & 0.33 & -68.946 & 20.835 & $0.006 * *$ & 0.27 \\
\hline Master's-PhD & -83.242 & 23.277 & $0.002 * *$ & 0.34 & -66.640 & 23.133 & $0.024 * *$ & 0.27 \\
\hline
\end{tabular}

* Significance adjusted by Bonferroni correction

** There were statistically significant differences

Table 2 Descriptive statistics of financial impacts and professional preparation

\begin{tabular}{llll}
\hline & & $\mathrm{N}$ & Percentage \\
\hline What was your income situation during the COVID-19 period? & Kept & 177 & $44.3 \%$ \\
& Reduced & 211 & $52.8 \%$ \\
& Increased & 12 & $3.0 \%$ \\
Have you ever used technological resources in your work? & Yes & 306 & $76.5 \%$ \\
Have you received any training from your educational institution & Yes & 94 & $23.5 \%$ \\
on how to carry out the activities? & & 122 & $30.5 \%$ \\
Total & No & 278 & $69.5 \%$ \\
\hline
\end{tabular}

able to connect again to the world. This finding shows that during the pandemic, professional performance needed to reinvent itself, in addition to seeking new logics for its operation in technology (Farias \& Giordano, 2020). In an emergency situation, everyone needed to adapt quickly (Farias \& Giordano, 2020) so that the economic impacts (Nicola et al., 2020) of this professional sphere were mitigated.

When observing the characterization of the activities developed, sports activities were the predominant activities, which leads us to question how these activities were developed considering that the professionals' workplace was predominantly their homes. This highlights the importance of technological tools and their use in the sports environment, being characterized as fundamental for the progress of the profession, leading us to realize that the classes may have been adapted during this period, or that the performance athletes prioritized training, unlike a student who focuses on sport for health or leisure. In relation to this, Parnell et al. (2020) describe that the real consequences of the pandemic cannot yet be effectively measured, especially in the cases of sport, whether participatory, educational or performance. Thus, the sports world needs to prepare for such a situation (Mann et al., 2020). 


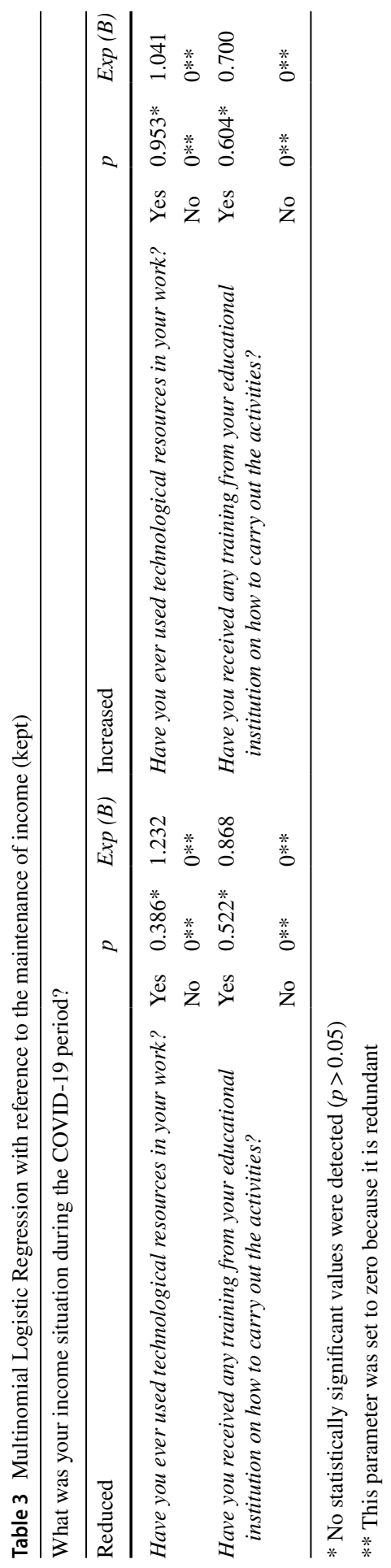


Impacts of the pandemic will still remain for a long time, impacts that will break with the epidemiological sphere, such as the fact of the levels of physical inactivity and sedentarism in society. Thus, finding ways for individuals to keep moving is of paramount importance (Chekroud et al., 2018; Mathieu et al., 2012; Pedersen \& Saltin, 2015; Powell et al., 2011), mainly because physical education professionals will have a lot of work to recover from "injuries" and consequences of this pandemic (Gilat \& Cole, 2020). The period of social distancing caused by the pandemic of COVID-19 (Bezerra et al., 2020) evidenced the potential of using remote mechanisms for pedagogical intervention in the movement of bodies. Thus, Distance Learning was characterized as a positive tool for use in the area of Physical Education during the social isolation provided at this time, being even observed by professionals as a positive strategy for future use.

It is understood that the pandemic and social distancing can result in differentiated impacts on society and that the most vulnerable population is the one that suffers the most, since unemployment, decreased income and the lack of necessary resources directly affect this public (Werneck \& Carvalho, 2020). In addition, it is low-income families who experience the greatest difficulties, considering the existence of numerous and crowded dwellings (Cluver et al., 2020). Nonetheless, the fact that the social class of the participants was not identified in the present study can be characterized as a limitation of this research.

\section{Final considerations}

The period of social distancing caused by the coronavirus pandemic (SARS-CoV-2) is characterized as an effective proposal to control the spread of the virus causing the disease COVID-19, however, it changes the social dynamics of individuals in society. Based on this question, the present study aimed to understand how was the performance of Brazilian physical education professionals during this period of social distancing in the pandemic of COVID-19.

With the completion of the study, it became evident that physical education teachers sought new intervention strategies so that they could continue with their professional performance, even with the changes induced in their realities. Distance learning carried out through different platforms was a strategy used and well regarded by professionals, regardless of whether they already had knowledge and familiarity with such tools, or whether they received specific training from their work institutions and organizations. However, even with the use of these strategies, the income of these professionals fluctuated during the pandemic. In addition, the academic degrees of the participants directly impacted the change in the number of hours worked.

Such findings reaffirm the weight of academic degrees on the workload of professional practice and demonstrate the effectiveness of using various electronic platforms in the area of Physical Education, whose central work object is the human movement, regardless of its manifestation. 
Authors' contributions All authors contributed extensively to the work presented in this paper.

Funding This study was carried out with the support from the Coordination for the Improvement of Higher Education Personnel_-Brazil (CAPES)_Financing Code 001.

Data availability The datasets analyzed are available from the corresponding author.

Code availability Not applicable.

\section{Declarations}

Ethics approval Federal University of Paraná, CAAE 88770618.4.0000.0102, opinion 2.748.001.

Conflicts of interest No potential conflict of interest.

\section{References}

Agresti, A., \& Finlay, B. (2012). Métodos estatísticos para as ciências sociais. Penso Editora.

Aquino, E. M. L., Silveira, I. H., Pescarini, J. M., Aquino, R., Souza-Filho, J. A. de, Rocha, A. dos S., ... Lima, R. T. dos R. S. (2020). Medidas de distanciamento social no controle da pandemia de COVID-19: potenciais impactos e desafios no Brasil. Ciência \& Saúde Coletiva, 25, 2423-2446. https://doi.org/10.1590/1413-81232020256.1.10502020.

Bastos, S. B., \& Cajueiro, D. O. (2020). Modeling and forecasting the early evolution of the Covid-19 pandemic in Brazil. arXiv preprint. Available in: https://covid-19.conacyt.mx/jspui/handle/1000/ 4048. Accessed 30 March 2020.

BBC. (2020). Coronavirus confirmed as pandemic by World Health Organization. Available in: https://www.bbc.com/news/world-5183994. Accessed 30 March 2020.

Bezerra, A. C. V., da Silva, C. E. M., Soares, F. R. G., \& da Silva, J. A. M. (2020). Fatores associados ao comportamento da população durante o isolamento social na pandemia de COVID-19. Ciência \& Saúde Coletiva, 25, 2411-2421. https://doi.org/10.1590/1413-81232020256.1.10792020.

Chekroud, S. R., Gueorguieva, R., Zheutlin, A. B., Paulus, M., Krumholz, H. M., Krystal, J. H., \& Chekroud, A. M. (2018). Association between physical exercise and mental health in 1.2 million individuals in the USA between 2011 and 2015: a cross-sectional study. The Lancet Psychiatry, 5(9), 739-746. https://doi.org/10.1016/S2215-0366(18)30227-X.

Cluver, L., Lachman, J. M., Sherr, L., Wessels, I., Krug, E., Rakotomalala, S., ... McDonald, K. (2020). Parenting in a time of COVID-19. The Lancet, 395(10231). https://doi.org/10.1016/ S0140-6736(20)30736-4.

Corriere della Sera. ([s.d.]). Coronavirus, primi due casi in Italia. Available in: https://www.corriere. it/cronache/20_gennaio_30/coronavirus-italia-corona-9d6dc436-4343-11ea-bdc8-faf1f56f19b7. shtml. Accessed 30 March 2020.

Corsini, A., Bisciotti, G. N., Eirale, C., \& Volpi, P. (2020). Football cannot restart soon during the COVID-19 emergency! A critical perspective from the Italian experience and a call for action. British Journal of Sports Medicine, 54(20), 1186-1187. https://doi.org/10.1136/bjspo rts-2020-102306.

Cruvinel, F., Silva, A. M., Silva, M. Z. D., Almeida, G. C. F. D., \& Filho, A. L. (2015). A dinâmica, os principais problemas e as qualidades no desenvolvimento de um curso de licenciatura em Educação Física na modalidade a distância. Pensar a Prática, 18(3). http://www.revistas.ufg.br/ index.php/fef/article/view/34504/19042.

El país. (2020). Coronavirus chega à Espanha com uma série de infecções confirmadas. Available in: https://brasil.elpais.com/internacional/2020-02-25/catalunha-confirma-o-quinto-caso-decoronavirus-registrado-na-espanha.html. Accessed 30 March 2020.

Estadão. (2020). Hospital do Canadá afirma ter encontrado primeiro caso de coronavírus no país. Available in: https://saude.estadao.com.br/noticias/geral,hospital-do-canada-afirma-ter-encon trado-primeiro-caso-de-coronavirus-no-pais,70003173068. Accessed 30 March 2020. 
Farias, M. Z., \& Giordano, C. C. (2020). Educação em tempos de pandemia de COVID-19: Adaptação ao ensino remoto para crianças e adolescentes. Série Educar, 44. https://doi.org/10.36229/ 978-65-86127-64-5.

Field, A. (2009). Descobrindo a Estatística Usando o SPSS-5. Penso Editora.

Ganem, F., Mendes, F. M., Oliveira, S. B., Porto, V. B. G., Araujo, W., Nakaya, H., ... Croda, J. (2020). The impact of early social distancing at COVID-19 Outbreak in the largest Metropolitan Area of Brazil. MedRxiv - The preprint server for Health Sciences. https://doi.org/10.1101/2020. 04.06.20055103.

Gilat, R., \& Cole, B. J. (2020). Editorial Commentary: COVID-19, Medicine, and Sports. Arthroscopy, Sports Medicine, and Rehabilitation. https://doi.org/10.1016/j.asmr.2020.04.003.

Hammami, A., Harrabi, B., Mohr, M., \& Krustrup, P. (2020). Physical activity and coronavirus disease 2019 (COVID-19): specific recommendations for home-based physical training. Managing Sport and Leisure. https://doi.org/10.1080/23750472.2020.1757494.

International Olympic Committee. (2020). Communique from the international olympic committee (ioc) regarding the Olympic Games Tokyo 2020. Available in: https://www.olympic.org/news/ communique-from-the-international-olympic-committee-ioc-regarding-the-olympic-gamestokyo-202. Accessed 30 March 2020.

Lana, R. M., Coelho, F. C., Gomes, M. F. da C., Cruz, O. G., Bastos, L. S., Villela, D. A. M., \& Codeço, C. T. (2020). Emergência do novo coronavírus (SARS-CoV-2) e o papel de uma vigilância nacional em saúde oportuna e efetiva. Cadernos de Saúde Pública, 36. https://doi.org/10. 1590/0102-311X00019620.

Lewnard, J. A., \& Lo, N. C. (2020). Scientific and ethical basis for social-distancing interventions against COVID-19. The Lancet Infectious Diseases, 20(6), 631-633. https://doi.org/10.1016/S14733099(20)30162-6.

Mann, R. H., Clift, B. C., Boykoff, J., \& Bekker, S. (2020). Athletes as community; Athletes in community: Covid-19, sporting mega-events and athlete health protection. British Journal of Sports Medicine. https://doi.org/10.1136/bjsports-2020-102433.

Mathieu, R. A., Powell-Wiley, T. M., Ayers, C. R., McGuire, D. K., Khera, A., Das, S. R., \& Lakoski, S. G. (2012). Physical activity participation, health perceptions, and cardiovascular disease mortality in a multiethnic population: The Dallas Heart Study. American Heart Journal, 163(6), 1037-1040. https://doi.org/10.1016/j.ahj.2012.03.005.

Mello, J. G., Novaes, R. C., \& Telles, S. C. C. (2021). Educação Física Escolar a Distância: Análise de Propostas para o Ensino Remoto. EaD Em Foco, 10(3). https://eademfoco.cecierj.edu.br/index.php/ Revista/article/view/1094.

Nicola, M., Alsafi, Z., Sohrabi, C., Kerwan, A., Al-Jabir, A., Iosifidis, C., ... Agha, R. (2020). The socioeconomic implications of the coronavirus pandemic (COVID-19): A review. International Journal of Surgery, 78, 185-193. https://doi.org/10.1016/j.ijsu.2020.04.018.

Olympic. (2020). Joint statement from the international olympic committee and the Tokyo 2020 organising committee. Available in: https://www.olympic.org/news/joint-statement-from-the-internationalolympic-committee-and-the-tokyo-2020-organising-committee. Accessed 30 March 2020.

Pappa, S., Ntella, V., Giannakas, T., Giannakoulis, V. G., Papoutsi, E., \& Katsaounou, P. (2020). Prevalence of depression, anxiety, and insomnia among healthcare workers during the COVID-19 pandemic: A systematic review and meta-analysis. Brain, Behavior, and Immunity, 88, 901-907. https:// doi.org/10.1016/j.bbi.2020.05.026.

Parnell, D., Widdop, P., Bond, A., \& Wilson, R. (2020). COVID-19, networks and sport. Managing Sport and Leisure, 0472, 1-7. https://doi.org/10.1080/23750472.2020.1750100.

Pedersen, B. K., \& Saltin, B. (2015). Exercise as medicine-evidence for prescribing exercise as therapy in 26 different chronic diseases. Scandinavian Journal of Medicine \& Science in Sports, 25, 1-72. https://doi.org/10.1111/sms.12581.

Powell, K. E., Paluch, A. E., \& Blair, S. N. (2011). Physical Activity for Health: What Kind? How Much? How Intense? On Top of What? Annual Review of Public Health, 32(1), 349-365. https://doi.org/10. 1146/annurev-publhealth-031210-101151.

Tass. (2020). First novel coronavirus case reported in Australia. Available in: https://tass.com/world/ 1112907. Accessed 30 March 2020.

Wang, G., Zhang, Y., Zhao, J., Zhang, J., \& Jiang, F. (2020). Mitigate the effects of home confinement on children during the COVID-19 outbreak. The Lancet, 395(10228), 945-947. https://doi.org/10.1016/ S0140-6736(20)30547-X. 
Werneck, G. L., \& Carvalho, M. S. (2020). A pandemia de COVID-19 no Brasil: crônica de uma crise sanitária anunciada. Cadernos de Saúde Pública, 36(5). https://doi.org/10.1590/0102-311X000688 20.

World Health Organization. ([s.d.]). Coronavirus. Available in: https://www.who.int/health-topics/coron avirus\#tab=tab_1. Accessed 30 March 2020.

Publisher's note Springer Nature remains neutral with regard to jurisdictional claims in published maps and institutional affiliations. 